\title{
Experimentos virtuais no estágio supervisionado de Física+*
}

\author{
Ivanderson Pereira da Silva ${ }^{1}$ \\ Universidade Federal de Alagoas \\ Emanuelly Torres Nunes ${ }^{2}$ \\ Luis Paulo Leopoldo Mercado \\ Universidade Federal de Alagoas \\ Maceió - AL
}

\section{Resumo}

Esse estudo investiga as contribuições dos experimentos virtuais para a formação de professores de Física. Teve por objetivos explorar as potencialidades didáticas dos experimentos virtuais a partir do componente curricular estágio supervisionado e analisar as contribuições desses recursos para a formação inicial de professores de Física. Trata-se de uma pesquisa de natureza qualitativa que se deu a partir da análise da experiência de exploração dos experimentos virtuais, na qual foram utilizados como técnica de coleta de dados a observação direta, os diários de campo e a gravação, em áudio, de um grupo focal realizado com os estagiários. Os dados coletados foram transcritos e submetidos à Análise Textual Discursiva que favoreceu sua categorização e interpretação. Como resultado desses movimentos, constatou-se que os modelos empirista e apriorista são muito persistentes no ideário pedagógico dos sujeitos da docência em Física, mesmo entre aqueles que estão em processo de formação inicial. Verificamos que mesmo reconhecendo o modelo construtivista como uma abordagem ideal para o trabalho com experimentos virtuais, as condições objetivas do trabalho docente e o ideário pedagógico desses professores em formação, determinaram que as práticas pedagógicas com experimentos virtuais se concentrem em torno de

\footnotetext{
${ }^{+}$Virtual experiments at the teaching practice of Physics teacher

* Recebido: abril de 2016.

Aceito: agosto de 2016.

1 E-mail: ivanderson@gmail.com

2 E-mail: emanuelly_torres@hotmail.com

3 E-mail: luispaulomercado@gmail.com
} 
demonstrações cujas principais funções são despertar a curiosidade dos alunos, motivá-los, contextualizar o conteúdo abordado e ilustrar fenômenos que foram anteriormente expostos pelo professor. Observou-se também que o moderador desempenha um papel central na problematização. Em razão dessa abordagem, embora em face das limitações impostas pela precariedade do sistema público de Educação, os sujeitos puderam ampliar suas concepções acerca da ciência e de seu desenvolvimento.

Palavras-chave: Formação de professores; Experimentos virtuais; Estágio supervisionado.

\begin{abstract}
This study investigates the contributions of virtual experiments for teaching and training of Physics teachers. We aimed to the educational potential of virtual experiments from teaching practice and analyzing the contributions of these resources for the initial formation of Physics teachers. This is a qualitative research that was carried out through the analysis of the operating experience of virtual experiments, by using direct observation, field diaries and áudio recording as data collection technique. Data were transcribed and submitted to Textual Discursive Analysis that favored their categorization and interpretation. As a result of these movements, it was found that the empirical models and aprioristic are very persistent in the pedagogical mind of the teachers, even among those who are in initial formation. We found that while recognizing the constructivist model as an ideal approach to work with virtual experiments, the objective conditions of teaching and the pedagogical ideas of these teachers in training, determined that the pedagogical practices with virtual experiments to focus around demonstrations whose main functions are arouse the curiosity of students, motivate them, contextualize the analyzed content and illustrate phenomena that were previously exposed by the teacher. It was also observed that the moderator plays a central role in problematic. Because of this approach, although by the limitations imposed by the precariousness of the public system of education, the subjects were able to expand their conceptions about Science and its development.
\end{abstract}


Keywords: Teacher training; Virtual experiments; Supervised internship.

\section{Introdução}

O cenário contemporâneo permite aos professores vislumbrarem as tecnologias digitais da informação e da comunicação (TDIC) como poderosos recursos de suporte à experimentação em aulas de Física (SANTOS; SILVA, 2016; HEIDEMANN et al., 2012; LIMA; TAKAHASHI, 2013; MEDEIROS; MEDEIROS, 2002; YAMAMOTO; BARBETA, 2001). Estudos como os de Silva et al. (2012) apontam que o uso desses recursos pode ser motivador para os envolvidos na prática pedagógica, porém é preciso cuidar para que sua exploração didática não favoreça a formação de imagens equivocadas sobre como a ciência nasce e/ou se desenvolve.

Em sintonia com a necessidade de explorar as potencialidades didáticas desses recursos, mas preocupados em criar estratégias que favorecem uma educação científica no cenário da formação de professores de Física (CHASSOT, 2003), propusemos no primeiro semestre de 2014 a exploração e análise de experimentos virtuais no âmbito do componente curricular Estágio Supervisionado 3, ofertado ao curso de Licenciatura em Física da Universidade Federal de Alagoas (UFAL), Campus de Arapiraca. Nessa oportunidade foram realizadas, em paralelo com as atividades de campo, reflexões acerca da experimentação com experimentos físicos e da experimentação virtual em Física. Tais reflexões se desenvolveram em dois espaços: em encontros quinzenais no Campus e debates em fóruns online no ambiente virtual Moodle ${ }^{4}$.

O acompanhamento dessa proposta nos despertou para a necessidade de compreender a relação entre o uso de experimentos virtuais em aulas de Física e suas contribuições para a formação desses futuros professores. Assim, delineamos o seguinte problema: "Quais as contribuições dos experimentos virtuais para o ensino e para a formação de professores de Física”?

Essa investigação teve por objetivos: explorar as potencialidades didáticas dos experimentos virtuais a partir do componente curricular estágio supervisionado e analisar as contribuições desses recursos para a formação inicial de professores de Física. Trata-se de uma pesquisa de natureza qualitativa (FLICK, 2009; BOGDAN; BIKLEN, 1994) que se deu a partir da análise da experiência de exploração dos experimentos virtuais, na qual foram utilizados como técnica de coleta de dados a observação direta, os diários de campo e a gravação em áudio de um grupo focal realizado com os estagiários ao final da experiência. Os dados coletados foram transcritos e submetidos à Análise Textual Discursiva (ATD) (MORAES; GA-

\footnotetext{
${ }^{4}$ Moodle é o acrônimo de Modular Object-Oriented Dynamic Learning Environment. Trata-se de um ambiente virtual de aprendizagem, desenvolvido por Martin Dougiamas segundo o paradigma do software livre e que vem sendo aperfeiçoado por pesquisadores do mundo inteiro. A UFAL, vem utilizando o Moodle desde 2006 para o desenvolvimento de seus cursos de extensão, graduação e pós-graduação <http://ava.ead.ufal.br>.
} 
LIAZZI, 2006, 2013; MORAES, 2003) a partir da qual foram unitarizados em fragmentos de significado, organizados em categorias e, por fim, produzido um metatexto no qual foram expressas as concepções dos sujeitos da pesquisa acerca das contribuições dos experimentos virtuais para o ensino e a formação inicial de professores de Física.

As próximas sessões desse trabalho estão organizadas da seguinte forma: num primeiro momento são apresentados os conceitos de experimento, experimentação e experimentos virtuais; na sequência é apresentada a proposta do Estágio Supervisionado que vem sendo realizada nos cursos de Formação de professores de Física na UFAL; posteriormente apresentamos um relato de experiência da modalidade Estágio de Docência Online desenvolvida no componente Estágio Supervisionado 3, no primeiro semestre de 2014, com oito alunos do curso de Licenciatura em Física da UFAL, Campus de Arapiraca; por fim, apresentaremos os procedimentos e os resultados da ATD realizada com base na transcrição da gravação em áudio de um grupo focam realizado junto com os sujeitos dessa experiência.

\section{Experimentação e experimentos virtuais no Ensino de Física}

Nas últimas décadas, observamos um aumento da exploração de recursos digitais em meio à comunidade de professores e de pesquisadores em educação e em ensino de Física (NUNES, 2015; SILVA; MERCADO, 2015). Dentre esses recursos, apontamos as simulações que reproduzem experimentos virtuais (SANTOS; SILVA, 2016; LIMA; TAKAHASHI, 2013; MEDEIROS; MEDEIROS, 2002). Segundo Borges e Moraes (1998, p. 30) apud Silva et al. (2012, p. 147), experimentar é "submeter à experiência; é pôr à prova; é ensaiar; é conhecer ou avaliar pela experiência". O experimento diz respeito à identificação de variáveis que são "manipuladas de maneira pré-estabelecida e seus efeitos suficientemente controlados pelo pesquisador para observação do estudo" (FACHIN, 2006, p. 40). Com base nessa concepção, entendemos os experimentos virtuais como recursos digitais interativos que simulam experimentos possíveis, ou não, de serem realizados num ambiente convencional de laboratório.

Por meio desses recursos, podemos fazer visitas a museus de ciência, aceleradores de partículas, viajar pelo corpo humano, observar eventos como a explosão de supernovas galácticas, buracos negros, acompanhar o movimento e a órbita dos planetas ou mesmo manipular experimentos que envolvam radiações alfa, gama e beta, impossíveis de serem realizados num ambiente de sala de aula convencional (LONGHINI; MENEZES, 2010; OURIQUE et al., 2010).

Esse tipo de proposta didática, diferente daquelas que acontecem por meio de aulas experimentais físicos ou aulas de campo, pode ser realizada em qualquer dia da semana indefinidamente, de forma individual ou coletiva, sem a necessária supervisão direta do professor e isento de riscos à integridade do corpo (MEDEIROS; MEDEIROS, 2002).

No laboratório da escola ou da universidade, geralmente, existem procedimentos 
específicos a serem realizados a partir de instrumentos laboratoriais com vistas à análise de determinado fenômeno. Normalmente em uma atividade desse tipo os estudantes realizam as tarefas em grupo problematizando a questão, levantando hipóteses, apontando evidências, comparando diferentes métodos e arranjos experimentais, manipulando os recursos físicos e avaliando os resultados obtidos. Existem ainda tempos e espaços determinados para a realização de atividades experimentais que, em função do atual cenário das escolas brasileiras, dificilmente poderiam se constituir numa prática contínua (MARTíN et al., 2014).

Outros fatores concorrem para limitar a prática experimental nas escolas tais como: falta de espaço físico para o laboratório de Física (HEIDEMANN et al., 2012); falta de materiais ou equipamentos defasados; grande quantidade de alunos nas salas de aula (SECCO; SECCO, 2013); formação deficiente do professor (BORGES, 2006); ausência de incentivos e inovações (LINS et. al., 2014); falta de tempo para o planejamento e a preparação dos experimentos (MARTíN et al., 2014); dificuldades no manuseio e na condução do trabalho experimental (SILVA JUNIOR et al., 2013), falta de clareza sobre o papel da experimentação na aprendizagem dos alunos (PEREIRA, 2010), dentre outros. Diante desses limitadores, a prática com experimentos virtuais, no contexto da Educação Básica, pode se constituir numa alternativa para que esses alunos não façam sua formação escolar sem ter acesso à prática de experimentação.

Atualmente é possível encontrar na internet muitos laboratórios virtuais que disponibilizam simulações de experimentos de Física. Assim como nos laboratórios tradicionais, os laboratórios virtuais podem ser entendidos como ambientes nos quais são realizados os experimentos. São espaços em que são realizados procedimentos de experimentação, sejam demonstrativos; comprobatórios, ou investigativos (LIMA; TEIXEIRA, 2011; BASSOLI, 2014).

Na experimentação demonstrativa, o professor assume o papel de experimentador e apresenta aos alunos a prática e os resultados experimentais. Na experimentação comprobatória, os alunos são desafiados a experimentar, mas para isso seguem um roteiro experimental rígido, com protocolo definido e que deve ser executado tal como foi apresentado. Variações no protocolo e mudanças nos resultados são entendidos como erros e devem ser evitados. Já na experimentação investigativa, os alunos são autores da problematização, do levantamento de hipóteses, a argumentação e diálogo entre eles faz parte da construção coletiva do procedimento experimental, o roteiro é aberto e o professor funciona como um orientador da prática. $\mathrm{O}$ erro não é visto como algo necessariamente ruim, podendo se constituir como um elemento disparador de debates e que pode encaminhar o grupo para novas problematizações (CARVALHO et al., 2013; GASPAR; MONTEIRO, 2005).

Variadas abordagens experimentais se apoiam em concepções epistemológicas distintas. A esse respeito, para Silva et al. (2012, p. 129), "quando pensamos nas práticas escolares de sala de aula, podemos dizer que existem, de maneira geral, três modelos 
principais que inspiram as noções de ensino e aprendizagem". São eles: o modelo empirista, o modelo apriorista e o modelo construtivista.

O empirismo, pensamento dominante e estruturador da ciência moderna, considera que a realidade existe independente do sujeito e que cabe a esse, meramente apreendê-la. $\mathrm{O}$ empirismo pautado na racionalização de procedimentos, por meio de métodos próprios, definiu o ponto de ruptura com "as práticas de investigação vigentes, que consideravam ainda uma estreita relação da natureza e do homem com o divino [...]" (GIORDAN, 1999, p. 43). Os dois métodos empiristas que se tornaram hegemônicos foram o método indutivo, proposto por Francis Bacon; e o método dedutivo, proposto por René Descartes.

Silva et al. (2012, p. 130), consideram que, segundo o método indutivo, "todo conhecimento é originado na observação e na experimentação, seguidas por uma generalização indutiva, a formulação de hipóteses; posteriormente se busca a verificação, [...] [e por fim] a formalização do conhecimento". Num movimento inverso ao do método indutivo, está o método dedutivo proposto por Descartes, segundo o qual a influência causal de pelo menos um enunciado geral sobre um evento particular ganha mais força na medida em que o percurso entre o enunciado geral e o evento particular é preenchido por eventos experimentais (GIORDAN, 1999). Essas são as bases a ciência moderna que combateu o pensamento aristotélico, no qual a experiência tinha base na observação natural, e contribuiu para a estruturação do método científico proposto na modernidade.

Os preceitos de Bacon e as concepções de Descartes foram tratadas por Augusto Comte como as bases da filosofia positiva. Na perspectiva positivista, "a experimentação exerce a função não só de instrumento para o desenvolvimento dessas competências, mas também de veículo legitimador do conhecimento científico" (GIORDAN, 1999, p. 43). Na perspectiva positivista, "a ciência é uma verdade incontestável. Sua validade é defendida e comprovada pelo método científico, o qual não permite a existência de dúvidas quanto ao conhecimento produzido por ela" (SILVA et al., 2012, p. 130). O rigor empírico é o fundamento da prática científica para se chegar à verdade. Dentro da concepção positivista é possível identificar uma verdadeira aversão ao erro. Esse, deve a todo custo ser evitado.

O modelo apriorista se baseia no pensamento idealista segundo o qual a realidade não existe. Segundo Rosa (1999, p. 289), "para os filósofos idealistas, não existe nenhuma realidade independente do sujeito que pensa, do espírito que apreende. A realidade é ela mesma determinada pela existência ou não de um espírito que conhece. Sem espírito não há realidade". Assim, aprendem os que têm vocação e dom para o campo de conhecimento e o meio pode apenas potencializar ou estimular a emergência desses talentos inatos (SILVA et al., 2012). Nesse cenário, a experimentação serve muito mais como elemento motivador ou despertador de talentos, do que como meio de aprendizagem.

Por fim, a experimentação segundo o modelo construtivista, "traz a possibilidade de o professor problematizar aquilo que está ocorrendo com o experimento. Seria o caso de fazer perguntas com a intenção de provocar dúvidas e desestabilizar as concepções que os alunos já 
criaram em torno do fenômeno" (SILVA et al., 2012, p. 133). Nessa perspectiva, a ciência é vista como um produto humano e como tal, mutável. Nesse sentido, a problematização do que ela estabelece se faz sempre presente no momento da experimentação. Em vez de protocolos rígidos que buscam reconstruir caminhos que garantam a comprovação de leis, teorias ou princípios científicos, a experimentação construtivista explora protocolos abertos que permitem aos sujeitos criarem percursos próprios e com eles aprender e produzir novos conhecimentos. Nesse cenário, o professor não está no centro. "A intencionalidade pedagógica do professor será a de criar condições para que os alunos possam reconstruir suas hipóteses, e não para que comprovem esta ou aquela teoria estudada em aula" (op. cit, p.133). Ele atua como um orientador, estimulando os debates e problematizando situações emergentes. O aluno é autor e sujeito responsável por sua própria aprendizagem e por contribuir para a aprendizagem de seus pares. Uma das principais abordagens construtivistas, nesse cenário, é a experimentação investigativa.

Segundo Lima e Teixeira (2011, p. 10), a abordagem experimental investigativa amplia "o sentido dos fenômenos e o significado das descrições científicas presentes nas discussões e atuação do ensino das ciências". Em vez de manipular os experimentos com vistas à observação de como o fenômeno pode ser modelado, ou mesmo de comprovar experimentalmente aquilo que afirma a teoria, dentro dessa abordagem os alunos são desafiados a resolver um problema utilizando a experimentação. Geralmente a solução desse problema é realizada colaborativamente (BASSOLI, 2014; GIORDAN, 1999).

Lima e Teixeira (2011), entendem que os experimentos investigativos são "aqueles que problematizavam e consideravam possíveis respostas, sem roteiro pré-definido e rigoroso e sem resultados pré-determinados". Para Bassoli (2014, p. 581) os experimentos investigativos envolvem "obrigatoriamente, discussão de ideias, elaboração de hipóteses explicativas e experimentos para testá-las". Nessa perspectiva, o aluno formula questões, planeja e implementa investigações para apresentar respostas ao problema proposto. Num exercício argumentativo mediado pelos experimentos, os sujeitos podem apresentar ideias e testá-las no sentido de produzir conhecimento e não apenas seguir roteiros que objetivam legitimar teorias ou leis já apresentadas.

Tais abordagens experimentais podem explorar recursos físicos como os aparatos experimentais tradicionais presentes nos laboratórios de ciências, ou explorar recursos lógicos como os experimentos virtuais disponíveis em laboratórios virtuais da internet. Dentre os laboratórios virtuais mais explorados pela comunidade de professores de Física é possível apontar o Phet Interactive Simulations (PhET) da Universidade do Colorado, desenvolvido pelo grupo do físico americano Carl Wieman, ganhador do Prêmio Nobel de Física de 2001. Segundo Pinheiro et al. (2015, p. 2047),

O PhET é um Portal que oferece gratuitamente muitos softwares de simulações de fenômenos Físicos, Químicos e Biológicos baseados em pesquisas realizadas por vários pesquisadores de diversas Universidades do mundo. O objetivo desse projeto 
é auxiliar os professores com o material de apoio em aulas teóricas, bem como ajudar os alunos a compreenderem os conceitos teóricos abstratos de forma interativa e divertida. As simulações estão disponíveis no Portal PhET, em português, e podem ser baixadas gratuitamente em computadores, tabletes e smartphones desde que os mesmos tenham o Java ou Flash para executarem as simulações.

Esse laboratório de experimentos virtuais disponibiliza de forma gratuita simulações/animações nas áreas de Física, Química, Matemática, Biologia e Ciências da Terra. O site está disponível em 37 idiomas, dentre os quais o português. As simulações do PhET podem ser exploradas diretamente a partir da internet ou podem ser baixadas gratuitamente sem a necessidade de cadastro.

Para Miranda et al. (2011, p. 5), o "PhET possui uma abordagem baseada em pesquisa, na qual as simulações são planejadas, desenvolvidas e avaliadas antes de serem publicadas no site". Esses autores complementam esse dado acrescentando que "além de produzir as simulações, a equipe do PhET busca realizar uma avaliação da eficiência de seu uso em salas de aula" (p. 2).

A "equipe faz um trabalho exaustivo de avaliação de sua eficácia no processo ensinoaprendizagem, para isso, elas são testadas com aproximadamente dezenas de estudantes" (SOUZA et al., 2012, p. 4). Esse controle de qualidade faz com que as simulações produzidas e disponibilizadas no PhET sejam, cada vez mais, utilizadas nas práticas pedagógicas dos professores de Física do mundo inteiro, por seu grau de confiabilidade.

Nesse sentido, o uso de experimentos virtuais nas práticas de formação de professores de Física se apresenta como uma possibilidade para o desenvolvimento de estratégias didáticas que podem enriquecer a docência na área no contexto da Educação Básica. Essa possibilidade foi explorada no âmbito do Estágio Supervisionado 3 ofertado no Curso de Licenciatura em Física da UFAL.

Trata-se dessa forma de uma pesquisa natureza qualitativa (FLICK, 2009; BOGDAN; BIKLEN, 1994) na qual foi analisada a experiência desse estágio supervisionado. A observação direta e o registro das vivências no âmbito desse componente curricular permitiram a descrição do caso e a realização de um grupo focal com os estagiários. Os dados coletados foram transcritos e submetidos à Análise Textual Discursiva (ATD) (MORAES; GALIAZZI, 2006 e 2013; MORAES, 2003) a partir da qual foram unitarizados em fragmentos de significado, organizados em categorias e, por fim, produzido um metatexto no qual foram expressas as concepções dos sujeitos da pesquisa acerca das contribuições dos experimentos virtuais para o ensino e a formação inicial de professores de Física.

Na sessão subsequente descreveremos a experiência do estágio supervisionado na qual foram explorados os experimentos virtuais. Os estagiários que participaram da experiência e forneceram dados para os encaminhamentos dessa investigação foram cognominados por E1, E2, E3, e assim por diante, tendo em vista a necessidade de preservar suas identidades. 


\section{O Estágio Supervisionado e a formação de professores de Física na UFAL utilizando experimentos virtuais}

Concorrem no ideário pedagógico brasileiro diferentes e divergentes ideias sobre a formação de professor e o estágio supervisionado. As concepções de prática, como a imitação de modelos, como instrumentalização técnica, ou de crítica à prática, polarizam as dimensões do estágio supervisionado valorizando uma concepção dicotômica desse componente curricular.

Para Marquezan e Fleig (2007, p. 35), "a prática docente é substância que caracteriza e qualifica particularmente". Caracteriza a teoria pelo fato de favorecer um aprofundamento da reflexão e qualifica o teor desta discussão construindo a identidade profissional do professor em formação. Esse processo implica uma articulação entre a teoria e a prática num movimento recursivo em que a teoria ilumina a prática e a prática se constitui num lócus privilegiado para a emergência de teorias.

Dada a sua importância para a formação da identidade profissional dos professores, o Parecer CNE/CP no 28/2001 definiu que o estágio supervisionado terá início a partir da segunda metade do curso reservadas 400 horas para seu desenvolvimento. As Diretrizes Curriculares Nacionais para a Formação de Professores, estabelecidas pela Resolução CNE/CP $n^{\circ} 2$ de $1^{\circ}$ de julho de 2015, ratificam esse posicionamento do Parecer CNE/CP n ${ }^{\circ}$ 28/2001 acerca do Estágio Supervisionado. Assim, tal componente curricular pode ser entendido como

\footnotetext{
o tempo de aprendizagem que, através de um período de permanência, alguém se demora em algum lugar ou ofício para aprender a prática do mesmo e depois poder exercer uma profissão ou ofício. Assim o estágio curricular supervisionado supõe uma relação pedagógica entre alguém que já é um profissional reconhecido em um ambiente institucional de trabalho e um aluno estagiário (BRASIL, 2001, p.10).
}

O estágio é o espaço no qual devem convergir todos os saberes do curso e por meio do qual a articulação desses saberes, sob a mediação e a supervisão de um profissional mais experiente permitirá a construção da identidade profissional desse professor em formação. Pimenta e Lima (2004) defendem que a melhor via para a efetivação dessa articulação entre teoria e prática é adotar, enquanto método, a valorização desses saberes por meio da formação do professor pesquisador. Tal concepção também é sustentada por Oliveira e Lampert (2007, p. 15), quando afirmam que o estágio é o "campo de conhecimento e espaço de construção cujo cerne é a pesquisa, ou seja, um lócus de perfil epistemológico".

Com base nessa concepção, foi pensado o Estágio no curso de Licenciatura em Física da UFAL. Silva (2012) apresenta as diferentes modalidades nas quais se desenvolve o estágio supervisionado no curso de licenciatura em Física da UFAL: estágio de observação, estágio de regência e estágio de docência online.

O estágio de observação é o momento no qual os alunos irão a campo fazer observações do espaço físico, infraestrutura, Projeto Político Pedagógico, bem como da prática 
pedagógica dos professores e com especial ênfase dos professores da área específica etc. Essas observações são registradas pelos estagiários com o objetivo de diagnosticar a situação na qual se encontra essa escola. O olhar do estagiário nesse momento é o olhar de um minerador que em seu ofício busca pedras brutas que precisam ser lapidadas. Ao diagnosticar os possíveis problemas vividos pela escola, o estagiário seja provocado a refletir sobre esses problemas buscando compreendê-los.

O estágio de regência é o momento em que o estagiário experimentará a docência compartilhada junto com professor de Física da escola na qual está estagiando. O planejamento e a prática de ensino são construídos juntos com o professor de Física da escola e socializados com o professor da universidade e com os colegas estagiários para que possam contribuir no sentido do aperfeiçoamento. $\mathrm{O}$ professor orientador e alguns estagiários podem acompanhar o momento da prática de ensino de um estagiário, ou de um grupo de estagiários. A reflexão na prática e sobre a prática é o grande motor do estágio de regência.

O estágio de docência online objetiva mobilizar saberes relacionados à prática pedagógica em Física mediada pelas TDIC. Nesse, os alunos são desafiados a desenvolver um plano de intervenção no qual explorem com máxima intensidade as potencialidades didáticas dos recursos digitais, dentre os quais os experimentos virtuais. Esse estágio de docência online reflete a preocupação do curso com a formação de recursos humanos para atuar na docência em espaços presenciais mediados pelas TDIC e em espaços virtuais tais como teleconferência, videoconferência, webaulas, educação por meio de computadores, etc. Para isso, comumente são utilizadas diferentes estratégias didáticas tais como: exibição ou criação de vídeos; audição de músicas ou criação de paródias; exposição de conteúdos por meio do uso do projetor multimídia; promoção de debates e seminários online; exposição e construção de experimentos de baixo custo com apoio à automação; modelagem computacional; uso de simuladores computacionais; uso do livro didático e paradidático online; mundos virtuais, jogos digitais, ambientes virtuais de aprendizagem (AVA), interfaces da web 2.0, etc. Assim como nos estágios anteriores, a reflexão na prática, e sobre a prática, definem o percurso nesse componente curricular.

Silva et al. (2015), Silva e Mata (2015) e Silva e Vieira (2015) analisaram as experiências do estágio de docência online desenvolvidas no curso de licenciatura em Física modalidade a distância da UFAL, ofertadas até 2015, e verificaram que os professores em formação têm conseguido desenvolver e aplicar práticas de ensino de Física mediadas pelas mais variadas TDIC, em suas turmas de regência no Ensino Médio. Diante dos resultados apontados nesses estudos, foi proposto, em caráter experimental, o desenvolvimento do estágio de docência online no componente curricular Estágio Supervisionado 3, ofertado no primeiro semestre letivo de 2014 , ao $7^{\circ}$ período do curso presencial de licenciatura em Física da UFAL Campus de Arapiraca, numa turma constituída por oito estudantes à época.

$\mathrm{Na}$ proposta desse estágio de docência online no curso presencial de Licenciatura em Física do Campus de Arapiraca da UFAL, estava o desafio da exploração. O desenvolvimento 
e aplicação de propostas didáticas com o uso de experimentos virtuais junto às turmas nas quais foram desenvolvidas as regências no Ensino Médio de aulas de Física. A regência de aulas foi desenvolvida a partir de um plano de intervenção didática, o qual tomou como fundamento as práticas em ensino de Física com o uso de experimentos virtuais.

A realização do Estágio de Docência Online no curso presencial de Licenciatura em Física da UFAL, Campus de Arapiraca, aconteceu em três espaços: a) na escola campo de estágio; b) nos encontros presenciais quinzenais ocorridos no espaço da universidade; c) debates online a partir de fóruns de discussão do AVA Moodle da UFAL.

No AVA Moodle, foram disponibilizados os documentos necessários para o encaminhamento ao campo de estágio (carta de encaminhamento, carta de aceite e registro de frequência). Também estava disponível um primeiro módulo no qual os alunos foram desafiados a explorar os experimentos virtuais e realizar uma seleção daqueles que melhor contribuiriam para a composição do material que utilizariam em sua prática de regência.

Para isso foi disponibilizada uma lista com indicações de laboratórios de experimentos virtuais (Quadro 1), com seus respectivos endereços eletrônicos, a partir dos quais esses sujeitos poderiam ter acesso a esses recursos.

Quadro 1 - Laboratórios Virtuais com Experimentos de Física.

\begin{tabular}{|l|l|}
\hline \multicolumn{1}{|c|}{ Laboratório Virtual } & \multicolumn{1}{c|}{ Site na Internet } \\
\hline HowStuffWorks? Como tudo Funciona & http://www.hsw.uol.com.br/ \\
\hline e-Física & http://www.cepa.if.usp.br/e-fisica/ \\
\hline Laboratório e Ciência & http://chemlab.byu.edu \\
\hline Experimentos Virtuais da UFRJ & http://www.if.ufrj.br/ marta/aplicativos \\
\hline Simulations and Games & http://www.mrmont.com/games/ \\
\hline Apllets Java de Física & http://www.walter-fendt.de/ph14br/ \\
\hline Physclips & http://www.animations.physics.unsw.edu.au/ \\
\hline Fisicanimada & http://www.ficicanimada.net.br \\
\hline Regents Exam Prep Center Physics & http://www.regentsprep.org/Regents/physics/physics.cfm \\
\hline Compadre & http://www.compadre.org \\
\hline Domínio Público & http://www.dominiopublico.gov.br/ \\
\hline DSpace & http://www.dspace.org/ \\
\hline CAREO & http://www.careo.org \\
\hline FREE & http://www.ed.gov/free \\
\hline Maricopa Learning Exchange & http://www.mcli.dist.maricopa.edu/mlx/ \\
\hline MERLOT & http://www.merlot.org \\
\hline PhET & http://phet.colorado.edu/ \\
\hline
\end{tabular}




\begin{tabular}{|c|c|}
\hline $\mathrm{BIOE}$ & http://objetoseducacionais2.mec.gov.br/ \\
\hline Pion & http://www.sbfisica.org.br/v1/novopion/ \\
\hline CESTA - CINTED & http://www.cinted.ufrgs.br/CESTA/cestadescr.html \\
\hline NUTED & http://www.nuted.ufrgs.br/objetos/ \\
\hline KlickEducação & http://www.klickeducacao.com.br/ \\
\hline Micro\&Gene & http://www.ib.usp.br/microgene/index.php?pagina=atividades \\
\hline RIVED-UNIFRA & http://sites.unifra.br/Default.aspx?alias=sites.unifra.br/rived \\
\hline Copyleft Perason & http://www.copyleftpearson.com.br/busca.aspx \\
\hline Science Netlinks & http://www.sciencenetlinks.com/ \\
\hline Intute & http://www.intute.ac.uk/ \\
\hline Wisc & http://www.wisc-online.com/ \\
\hline Profetic & http://www.profetic.org/ \\
\hline John Kirky’s Cell Biology Animation & http://www.johnkyrk.com/ \\
\hline Graxaim & http://www.graxaim.org/gmt/oa/termo/termolb.html \\
\hline Universidade do Minho Vlabs & http://vlabs.uminho.pt \\
\hline Laboratório Virtual da PUC-RJ & www.labvirtual.cbpf.br \\
\hline Laboratório Virtual de Física da UNILESTE & http://www.virtual.unilestemg.br/laboratorio/index.htm \\
\hline Sala de Física & www.saladefisica.com.br \\
\hline Laboratório Virtual de Física da UFSC & http://www.fsc.ufsc.br/ ccf/parcerias/ntnujava/index-port.html \\
\hline Ministério de Educacion Y Ciencia Espanha & http://w3.cnice.mec.es/recursos/rec-psb.htm \\
\hline Universidade de Oxford - Reuno Unido & www.ox.uc.uk \\
\hline LabVirt USP & www.labvirt.futuro.usp.br \\
\hline Rede Interativa Virtual de Educação & http://rived.proinfo.mec.gov.br \\
\hline
\end{tabular}

Fonte: Os autores

O desafio desse primeiro módulo foi explorar os experimentos virtuais, debater sobre eles no Fórum de Discussão intitulado "Dúvidas sobre a seleção de experimentos" e postar na tarefa "Seleção de Experimentos Virtuais" aqueles que, de acordo com os conteúdos que estavam sendo explorados nas escolas naquele momento e com base no entendimento dos estagiários, seriam os recursos que poderiam contribuir para o desenvolvimento da regência de aulas nas turmas do Ensino Médio.

A organização do desenho didático (SANTOS; SILVA, 2009) desse espaço no AVA Moodle pode ser verificado na Fig. 1.

Ao longo desse componente curricular, os alunos foram apresentados ao plano da disciplina que evidenciava a necessidade dos encontros quinzenais na universidade e, em pa- 
ralelo, os alunos deveriam desenvolver as atividades de regência na escola campo de estágio. Os encontros foram utilizados para compartilhar as experiências vivenciadas no campo de estágio, para exploração dos experimentos virtuais, desenvolvimento de propostas de intervenção didática e apresentação de micro aulas com o uso de experimentos virtuais. Os encontros quinzenais ocorridos no espaço da universidade foram registrados em diário de bordo e a síntese desses registros podem ser verificadas no quadro 2.

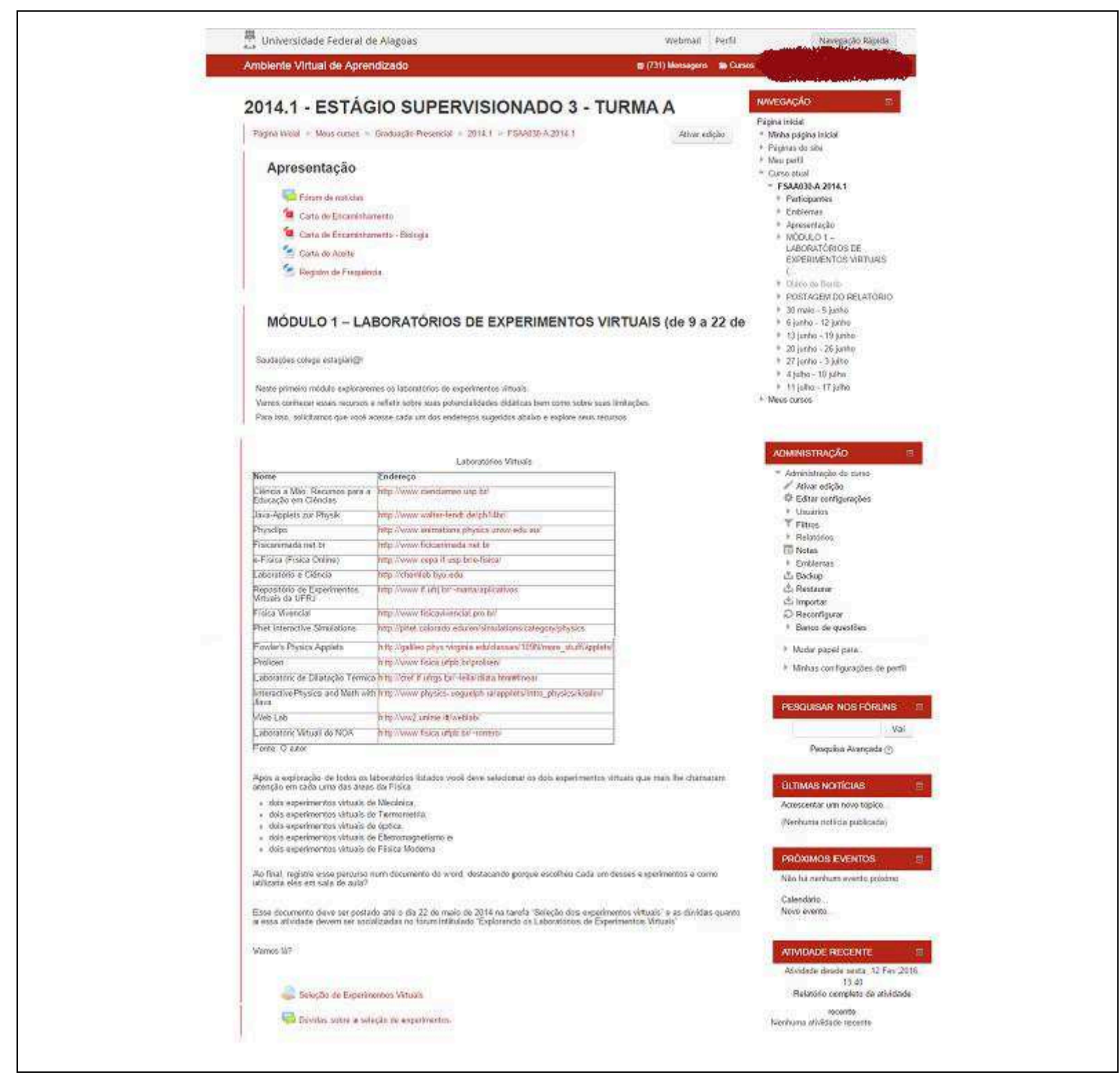

Fig. 1 - Desenho Didático do componente curricular Estágio Supervisionado 3 (2014.1) no AVA Moodle. Fonte: Captura de tela. AVA Moodle da UFAL. 2014 
Quadro 2 - Registros das observações dos encontros quinzenais na universidade.

\begin{tabular}{|c|c|}
\hline Encontro & Descrição do Encontro \\
\hline $\begin{array}{c}1^{\circ} \text { Encon- } \\
\text { tro }\end{array}$ & $\begin{array}{l}\text { Apresentação do plano de curso que detalhava a ementa, conteúdos, objetivos, metodologia, cro- } \\
\text { nograma e avaliação da disciplina de Estágio Supervisionado } 3 \text { para a turma do } 7^{\circ} \text { período do } \\
\text { curso de Licenciatura em Física da UFAL. }\end{array}$ \\
\hline $\begin{array}{l}2^{\circ} \text { Encon- } \\
\text { tro }\end{array}$ & $\begin{array}{l}\text { Os alunos compartilharam suas impressões sobre o encaminhamento ao campo de estágio e o } \\
\text { primeiro contato com a escola. Os alunos também explicitaram suas dúvidas com relação à elabo- } \\
\text { ração do projeto de intervenção a ser desenvolvido na regência. }\end{array}$ \\
\hline $\begin{array}{c}3^{\circ} \text { Encon- } \\
\text { tro }\end{array}$ & $\begin{array}{l}\text { Alguns alunos relataram que não conseguiram formalizar o encaminhamento ao campo de estágio } \\
\text { até o encontro anterior e por isso o fizeram com atraso. Outros informaram que já haviam inicia- } \\
\text { do o diálogo com o professor de Física da escola com o objetivo de compreender e aperfeiçoar o } \\
\text { planejamento já existente e identificaram a inatividade dos laboratórios de Informática e de Ciên- } \\
\text { cias das escolas. }\end{array}$ \\
\hline $\begin{array}{c}4^{\circ} \text { Encon- } \\
\text { tro }\end{array}$ & $\begin{array}{l}\text { Os alunos compartilharam suas primeiras experiências de regência nas aulas. Foi realizada a soci- } \\
\text { alização das experiências do estágio de regência, dificuldades e êxitos. Os alunos registraram que } \\
\text { estavam tendo dificuldades em introduzir os experimentos virtuais em suas aulas em função das } \\
\text { condições precárias dos laboratórios de informática e por não estarem seguros sobre como explo- } \\
\text { rá-los. }\end{array}$ \\
\hline $\begin{array}{c}5^{\circ} \text { Encon- } \\
\text { tro }\end{array}$ & $\begin{array}{l}\text { O professor apresentou um modelo de aula com o uso de experimentos virtuais, com o tema: "ne- } \\
\text { bulosas galácticas e o desvio para o vermelho". Para isso, fez uso de simulações do PhET } \\
\text { (http://migre.me/tphJi) e do Software Stellarium (http://www.stellarium.org/pt/). Solicitou aos } \\
\text { alunos que compusessem duplas e a partir do encontro seguinte apresentassem micro aulas com } \\
\text { duração de } 20 \text { min como apoio de experimentos virtuais. Para isso, o professor montou um crono- } \\
\text { grama que previa a apresentação de pelo menos duas micro aulas por encontro. }\end{array}$ \\
\hline & $\begin{array}{l}\text { Os alunos compartilharam seus avanços e dificuldades com a regência em aula e num segundo } \\
\text { momento iniciaram-se as apresentações das micro aulas. A primeira micro aula enfocou o tema } \\
\text { dilatação térmica. Nessa, a dupla utilizou a lousa e o projetor multimídia. Apresentaram o conte- } \\
\text { údo intercalando o uso da lousa e a apresentação de slides. Ao final da aula os alunos realizaram } \\
\text { simulações as quais reproduziam experimentos sobre dilatação linear (http://migre.me/tphIx e } \\
\text { http://migre.me/tphIV), superficial } \quad \text { (http://migre.me/tphGO) e volumétrica } \\
\text { (http://migre.me/tphHY). }\end{array}$ \\
\hline $\begin{array}{c}7^{\circ} \text { Encon- } \\
\text { tro }\end{array}$ & $\begin{array}{l}\text { Os alunos compartilharam seus avanços e dificuldades com a regência em aula e num segundo } \\
\text { momento foi dada sequência às apresentações das micro aulas. A segunda micro aula enfocou o } \\
\text { tema Energia Mecânica. A segunda dupla fez uma aula expositiva e, por fim, utilizaram uma si- } \\
\text { mulação do ambiente PhET (http://migre.me/tphOH), variando parâmetros e demonstrando seus } \\
\text { efeitos. Na sequência, a terceira micro aula enfocou o tema Oscilações. A terceira dupla utilizou } \\
\text { o projetor multimídia para apresentar slides sobre o tema e por fim, apresentaram uma simulação } \\
\text { a partir do site do professor Romero Tavares (http://migre.me/tphNQ). Analogamente ao caso } \\
\text { anterior, essa dupla demonstrou a simulação, fez variar seus parâmetros e mostrou os efeitos pro- } \\
\text { duzidos. }\end{array}$ \\
\hline
\end{tabular}




\begin{tabular}{|c|c|}
\hline $8^{\circ}$ Encon- & $\begin{array}{l}\text { Os alunos compartilharam seus avanços e dificuldades com a regência em aula e num segundo } \\
\text { momento foi dada sequência às apresentações das micro aulas. A quarta micro aula enfocou o } \\
\text { tema Movimento Retilíneo Uniforme (MRU). Nessa, a dupla utilizou o recurso vídeos de repro- } \\
\text { dução experimental e apresentação de slides com apoio do projetor multimídia. No vídeo os alu- } \\
\text { nos apresentavam cenas de movimento de carros e analisavam sequências de movimento que se } \\
\text { aproximavam do movimento retilíneo uniforme. O uso desse recurso teve o objetivo de apresentar } \\
\text { a aplicação dos princípios apresentados na exposição de slides. A quinta micro aula enfocou o } \\
\text { tema: Leis da Dinâmica Newoniana. Essa dupla utilizou a lousa, slides e um experimento virtual } \\
\text { (http://migre.me/tpiox). Apesar da exposição realizada ter sido permeada por questionamentos, } \\
\text { essa dupla também utilizou o experimento virtual ao final da exposição e para isso o fez demons- } \\
\text { trando os princípios expostos. A sexta micro aula enfocou o tema Vetores a partir da exploração } \\
\text { de recursos como ilustrações, vídeos e a lousa. Essa dupla aproveitou o momento de Copa do } \\
\text { Mundo de Futebol e utilizou imagens para explicar uma grandeza vetorial com o movimento da } \\
\text { bola. O vídeo utilizado exibia o momento de um acidente na BR } 376 \text { (http://migre.me/tpicO) e a } \\
\text { simulação da Joaninha em Movimento } 2 \mathrm{D} \text { (http://migre.me/tpidC) para explicar o efeito da acele- } \\
\text { ração e velocidade centrípeta. }\end{array}$ \\
\hline & $\begin{array}{l}\text { Os alunos compartilharam seus avanços e dificuldades com a regência em aula e num segundo } \\
\text { momento foi dada sequência às apresentações das micro aulas. A sétima e última micro aula en- } \\
\text { focou o tema Força Resultante. Para isso, fez uma exposição alternando o uso da lousa e o uso do } \\
\text { projetor multimídia por meio de uma apresentação de slides e, por fim, apresentou a simulação de } \\
\text { cabo de guerra da plataforma Phet (http://migre.me/tpini). }\end{array}$ \\
\hline $\begin{array}{l}10^{\circ} \text { Encon- } \\
\text { tro }\end{array}$ & $\begin{array}{l}\text { No décimo e último encontro da disciplina, os estagiários foram convidados a fazer uma análise } \\
\text { da disciplina. Para isso foi realizado um grupo focal o qual foi gravado com o apoio do gravador } \\
\text { do celular. Foram sugeridas algumas perguntas, referente ao problema dessa pesquisa, com a } \\
\text { participação ativa de toda a turma, e nesse momento estavam presentes oito estudantes. O grupo } \\
\text { focal teve a duração de } 45 \text { minutos, e como o grupo era homogêneo, com alunos da mesma turma } \\
\text { e que enfrentaram problemas parecidos nas escolas campos de estágio, as abordagens perante aos } \\
\text { questionamentos foram semelhantes. Por fim foram feitas algumas sugestões para a disciplina no } \\
\text { próximo semestre. }\end{array}$ \\
\hline
\end{tabular}

Fonte: Os autores

Observa-se a partir da descrição contida no quadro 2 que todas as duplas conseguiram explorar os experimentos virtuais variando com relação ao tema explorado e com relação às simulações exploradas. No entanto, chama atenção o fato de que todas as micro aulas exploraram os experimentos virtuais a partir de demonstrações experimentais. Essa posição não é neutra nem desinteressada.

Segundo Gaspar e Monteiro (2005), a demonstração experimental é a prática mais comum no contexto da experimentação em Física e é utilizada para favorecer "a visualização de fenômenos, verificação de leis ou medição de constantes físicas, independentemente de serem realizadas por alunos, individualmente ou em grupo, por um professor perante uma turma, ou por um palestrante diante de uma audiência" (CARVALHO et al., 2013, p. 44). 
Trata-se de uma estratégia de contextualização dos conteúdos, bem como um bom recurso quando se quer apresentar a uma turma um mesmo procedimento, no entanto o aprendizado de Física não pode ficar limitado à abordagem experimental demonstrativa. A forma como essa abordagem experimental foi conduzida, remonta ora a um modelo empirista, ora a um modelo apriorista, desconsiderando o modelo construtivista.

Chama atenção também o momento em que a experimentação se apresenta nessas micro aulas. Em todos os casos a experimentação sucedeu a exposição. O estagiário E3 afirmou que em suas aulas, "passava a teoria e depois usava a simulação como aplicação da teoria”, mas reconhece que essa não é a estratégia que considera ideal para a condução da prática pedagógica em Física. Essa alocação do experimento virtual no final das micro aulas também não é neutra nem desinteressada. Isso traduz a ideia de que se deve aprender a teoria para depois aplicar na prática. Sob esse aspecto, Menezes (1980, p. 90), desde a década de 1980, vem criticando a visão de que "seria preciso antes aprender o modelo microscópico para ser capaz de entender o fato macroscópico" e nesse sentido, afirma que "fatos físicos podem (e devem) ser mostrados e relacionados antes da apresentação de modelos abstratos e teorias" (idem p. $91)$.

Verifica-se ainda, no quadro 2, que o décimo encontro foi reservado para a análise da experiência vivenciada no Estágio Supervisionado 3. Nesse, foi proposto aos alunos que participassem de grupo focal no qual seriam socializadas as impressões de cada sujeito a respeito das contribuições dos experimentos virtuais para a docência em Física.

No décimo encontro quinzenal da disciplina, foi realizado o grupo focal com oito estagiários, o moderador e o professor responsável pelo Estágio. Um dos autores dessa pesquisa foi o moderador. Para a coleta das falas, foi utilizado, com o consentimento dos participantes, um gravador em áudio que captou 45 minutos de conversa. Esse material foi transcrito e submetido à ATD. Os resultados desse movimento de análise estão dispostos na sessão subsequente.

\section{A análise textual discursiva dos dados apresentados no estágio de docência online}

Segundo Moraes e Galiazzi (2006, p. 118), a ATD "é uma abordagem de análise de dados que transita entre [...] a análise de conteúdo e a análise de discurso". Nesse sentido se apoia tanto na interpretação do significado atribuído pelo autor quanto nas condições de produção de um determinado texto. Para Moraes (2003) a ATD se realiza a partir de quatro focos:

1. Desmontagem dos textos: também denominado de processo de unitarização, implica examinar os materiais em seus detalhes, fragmentando-os no sentido de atingir unidades constituintes, enunciados referentes aos fenômenos estudados. 
2. Estabelecimento de relações: processo denominado de categorização, implicando construir relações entre as unidades de base, combinando-as e classificando-as no sentido de compreender como esses elementos unitários podem ser reunidos na formação de conjuntos mais complexos, as categorias.

3. Captando o novo emergente: a intensa impregnação nos materiais da análise desencadeada pelos dois estágios anteriores possibilita a emergência de uma compreensão renovada do todo. O investimento na comunicação dessa nova compreensão, assim como de sua crítica e validação, constituem o último elemento do ciclo de análise proposto. $O$ metatexto resultante desse processo representa um esforço em explicitar a compreensão que se apresenta como produto de uma nova combinação dos elementos construídos ao longo dos passos anteriores. [...]

4. Um processo auto-organizado: o ciclo de análise descrito, ainda que composto de elementos racionalizados e em certa medida planejados, em seu todo constitui um processo auto-organizado do qual emergem novas compreensões. Os resultados finais, criativos e originais, não podem ser previstos. Mesmo assim é essencial o esforço de preparação e impregnação para que a emergência do novo possa concretizar-se (MORAES, 2003, p. 191-192).

Os três primeiros movimentos, unitarização, categorização e produção dos metatextos consistem num ciclo, um movimento recursivo por meio do qual o texto é desconstruído, fragmentado em pequenas unidades de significado. As unidades de significado podem ser agrupadas de acordo com temas preexistentes (categorias à priori), ou de acordo com temas que venham a surgir a partir da análise dos dados. Nesse segundo caso se tratam de categorias emergentes. O processo de agrupamento dos fragmentos do texto ou unidades de significado consiste na categorização. Esse movimento implica na reescrita desses fragmentos com vistas a produzir sentidos por meio dos metatextos (MORAES; GALIAZZI, 2013). Como afirma Moraes (2003), a ATD se constitui num movimento recursivo e auto-organizado por meio do qual "os resultados finais, criativos e originais, não podem ser previstos" (p. 192).

Para essa investigação submetemos o material transcrito a partir da gravação do grupo focal realizado com os estagiários à ATD. Inicialmente o texto foi fragmentado e ao reorganizar os fragmentos foi possível reuni-los em torno de seis categorias: (1) primeiros contatos com os experimentos virtuais; (2) dificuldades em utilizar os experimentos virtuais nas aulas de Física das escolas da Educação Básica; (3) limitações dos experimentos virtuais em relação aos físicos; (4) vantagens dos experimentos virtuais em relação aos físicos; (5) contribuições dos experimentos virtuais nas aulas de Física; e (6) metodologia ideal para o trabalho com experimentos virtuais.

A partir destas categorias foi feita a descrição e interpretação das relações das ideias dos alunos com o propósito de compreender as contribuições dos experimentos virtuais na formação de professores de Física. Ao longo da ATD alguns fragmentos unitarizados foram evocados para fundamentar os metatextos e seus autores foram cognominados E1 (estagiário 
1); E2 (estagiário 2), e assim por diante. Tal estratégia objetivou ser fiel à autoria do fragmento e ao mesmo tempo preservar sua identidade.

Apesar de apontarmos individualmente a autoria dos fragmentos unitarizados, entendemos que os diálogos promovidos no interior do grupo focal revelaram o entendimento do grupo e não o entendimento individual dos sujeitos. Nesse sentido, o produto dos metatextos busca explicitar, por meio da fragmentação e da reescrita desse diálogo, o pensamento coletivo desse grupo acerca da experiência vivenciada com o uso de experimentos virtuais no contexto do estágio supervisionado.

\section{a) Primeiros contatos com os experimentos virtuais}

$\mathrm{Na}$ realização do grupo focal, inicialmente foi questionado aos sujeitos se em outros momentos de sua formação acadêmica, já haviam tido contato com os experimentos virtuais? Como respostas, informaram que já haviam tido contato com esses recursos em outros componentes curriculares do curso: "no $3^{\circ}$ período, na disciplina de Física Experimental 1" (E6); "no $6^{\circ}$ período, na disciplina de Projetos Integradores 6" (E4); ou "na apresentação do software utilizado pelos colegas do PIBID" (E1).

Percebemos que nesse curso de formação de professores de Física, já havia a preocupação com a exploração desses recursos. Tal preocupação extrapola a exploração no cenário do Ensino Superior e se materializa nas práticas desenvolvidas nas escolas públicas pelos alunos do Programa Institucional de Bolsas de Iniciação à Docência (PIBID).

Chama atenção ao fato de que, mesmo já tendo experiências anteriores com os experimentos virtuais, esses sujeitos tiveram dificuldades em explorá-los de acordo com abordagens construtivistas. Se é sabido que "desde sua origem, o trabalho experimental nas escolas foi influenciado por aqueles desenvolvidos nas universidades" (MOREIRA, PENIDO, 2009, p. 2), é fundamental que se atualize não somente os recursos explorados nas práticas universitárias de ensino de Física, mas também a forma como tais práticas têm sido conduzidas.

$\mathrm{O}$ uso restrito dos experimentos virtuais bem como a forma como tais recursos vêm sendo explorados repercutem nos significados que os professores em formação atribuem a esses recursos. Em função da quantidade de laboratórios virtuais explorados nesse componente curricular esses estagiários revelaram que "não conhecia[m] a variedade de experimentos virtuais disponível nas plataformas" (E1) e o desconhecimento da amplitude desses recursos, bem como das possibilidades de uso deles, contribuiu para limitar a visão que esses sujeitos têm sobre as potencialidades didáticas dos experimentos virtuais.

Mesmo no caso dos estagiários que já exercem a docência nas escolas da região é possível considerar que esses sujeitos "não imaginava[m] que [os experimentos virtuais] poderia[m] ser utilizado[s] em sala de aula" (E5). O uso desses recursos, no ideário desses estagiários, se aproximava muito mais de um elemento motivador que contribuísse para despertar "a curiosidade" (E3) dos estudantes, não necessariamente como principais recursos em práticas de experimentação investigativa. 


\section{b) Dificuldades em utilizar os experimentos virtuais nas aulas de Física das escolas da educação básica}

O moderador questionou ao grupo focal quais tinham sido as principais dificuldades deles em trabalhar com os experimentos virtuais no contexto das atividades de regência nas escolas da Educação Básica. O primeiro elemento apontado foi a falta de tempo para a execução do planejamento realizado "pois necessita de preparos técnicos" (E5). Os "preparos técnicos" a que se refere E5 podem ser traduzidos como a reserva e a montagem do projetor multimídia, do equipamento de som e do computador na sala de aula. Nenhum desses alunos relatou práticas nos laboratórios de informática das escolas e a razão para tal era que "o laboratório de informática da escola não tinha aparelhos funcionando, então no período da regência só foi utilizado o projetor para reproduzir as simulações em sala de aula" (E8). Tal cenário reflete o estado precário em que se encontram as escolas públicas alagoanas e, consequentemente, sinaliza a magnitude dos esforços que os professores, individualmente, têm que realizar para poder planejar e desenvolver práticas experimentais no cenário na Educação Básica.

Além das limitações postas pela falta de recursos humanos que possam apoiar os professores de Física nas práticas experimentais e das precárias condições dos Laboratórios de Ciências e de Informática das escolas alagoanas, esses alunos acrescentam que "duas aulas semanais de Física é muito pouco, e é necessário muito tempo para utilizar os experimentos e cumprir com o planejamento escolar dos conteúdos. A situação piora para as turmas do curso noturno, onde são reduzidos o tempo das aulas" (E1).

Essa situação se agrava "quando a única maneira possível de utilizar o experimento na escola é através do projetor" (E3), pois assim "o tempo da aula não permite que todos os alunos possam manipular os experimentos" (idem). O estagiário E6 relata que "o laboratório de informática da escola não estava preparado para ser utilizado e tive que levar o experimento para ser demonstrado na sala de aula com o projetor". Já E7 acrescenta que "durante o período de regência foram encontrados laboratórios trancados, empoeirados, e com equipamentos quebrados, inviáveis de ser utilizados".

Além das carências na infraestrutura das escolas, também é possível observar a necessidade de promover estratégias que visem superar visões distorcidas sobre a ciência, dificuldades com a linguagem da Física (realização e interpretação de operações matemáticas, gráficos, tabelas, etc.), bem como os desafios de favorecer os caminhos para que esses sujeitos possam compreender o mundo físico em que estão inseridos e no qual o desenvolvimento científico e tecnológico está em profunda relação com questões de ordem ambiental, social, política e econômica.

As condições objetivas descritas pelos estagiários limitam as ações dos professores e, mesmo em face do esforço desses sujeitos para realizar atividades experimentais, o máximo que conseguem é promover demonstrações. Nessas práticas demonstrativas o estagiário "alterava os parâmetros que seriam modificados e explicava como o experimento funcionava, mas não tinha tempo para colocar cada aluno para manusear o experimento" (E2), uma vez que o 
recurso utilizado para fazer a demonstração era o projetor multimídia e a sala de aula, na maioria dos casos, só dispunha do laptop do próprio estagiário. Mesmo para o desenvolvimento dessas práticas, as condições objetivas se constituíam num elemento profundamente limitador, tendo em vista que pouca quantidade de projetores multimídia nas escolas, fazia com que os estagiários tivessem de "agendar com antecedência a sua utilização" (E4) (idem) e por vezes negociar com outros professores que haviam reservado o único projetor da escola para ser utilizado nas aulas de outras turmas.

Acerca das condições infraestruturais dos laboratórios das escolas, em 19 de abril de 2015 o jornal Gazeta de Alagoas publicou uma série de matérias nas quais foram divulgados resultados de um levantamento realizado pelo Ministério Público do Estado de Alagoas (MPE-AL) segundo o qual 14,9\% das escolas não tinham laboratórios instalados e 53,8\% dos Laboratórios de Ciências e de Informática não funcionam ou funcionam em condições extremamente precárias (GAZETA DE ALAGOAS, 2015). Isso significa que provavelmente, nas escolas em que os Laboratórios de Ciências estão sucateados, os Laboratórios de Informática também estão, dado que pode ser parcialmente verificado a partir da realização dessa experiência, o que claramente têm contribuído para limitar profundamente as práticas experimentais nas escolas, sejam elas baseadas em experimentos físicos ou virtuais.

Nesse sentido, as condições objetivas em que o trabalho docente se dá se constituem em fatores limitadores da prática experimental mesmo quando os experimentos são virtuais. $\mathrm{O}$ pouco tempo para o planejamento didático, a curta duração das aulas, a falta de recursos mínimos de internet, projetor multimídia e computador portátil, ou as péssimas condições dos laboratórios de informática, são alguns desses fatores.

\section{c) Limitações dos experimentos virtuais em relação aos físicos}

Além das condições objetivas é possível verificar que as ideias que os sujeitos têm sobre o papel dos experimentos físicos e o papel dos experimentos virtuais também contribuem para o uso e o não uso desses recursos. Ao serem questionados sobre a possibilidade dos experimentos virtuais virem a substituir os experimentos físicos, os alunos se posicionaram afirmando que "os experimentos virtuais podem complementar os experimentos físicos e não substituir, pois não se pode perder o contato com a situação física" (E8). Esses recursos "tornam-se uma alternativa viável para escolas que estão com laboratórios de ensino empoeirados e com equipamentos" (E4) e, nessa perspectiva, "se tiver laboratório de ensino na escola os experimentos físicos não podem ser substituídos totalmente pelos virtuais, mas pode haver a necessidade de complementação" (E1).

Para E7, "o fato de poder tocar, passaria a ser mais interessante do que a simulação virtual, o aluno observa que aquilo realmente está acontecendo, por isso os experimentos virtuais não podem substituir integralmente os físicos". Os perigos de utilizar apenas os experimentos virtuais podem estar relacionados inclusive à criação de visões distorcidas sobre como 
a ciência nasce e evolui. Uma vez que as simulações contidas nos experimentos virtuais tomam por base a definição de modelos aceitos pela comunidade científica atual, os resultados gráficos apresentados não podem ser confundidos com o que de fato acontece no mundo natural.

Preocupados com esse cenário, os alunos podem questionar "se a situação aconteceria da mesma maneira no cotidiano caso seja só utilizado experimentos virtuais" (E2) e, dessa forma, se posicionam a favor do uso de experimentos físicos e experimentos virtuais de forma combinada.

Assim, o uso dos experimentos virtuais por si só não é suficiente para promoção de uma autêntica educação científica. O uso exclusivo dos experimentos virtuais só se constitui numa alternativa viável para escolas que não possuem Laboratório de Ciências ou naquelas em que a realização de outras formas de experimentação, como o caso dos experimentos de baixo custo, não é possível. Tradicionalmente a experimentação com experimentos físicos não exigia a presença dos experimentos virtuais para favorecer os caminhos para a educação científica, mas parece que o movimento contrário não encontra respaldo junto aos professores e nem mesmo entre os pesquisadores da área. É preciso considerar ainda que, assim como a experimentação com experimentos físicos, a experimentação apoiada em experimentos virtuais exige tempo e dedicação do professor para seu planejamento e execução, bem como condições infra estruturais mínimas para que possa se materializar.

\section{d) Vantagens dos experimentos virtuais em relação aos físicos}

Ao serem questionados acerca das vantagens que os experimentos virtuais apresentavam para o trabalho pedagógico, os alunos apontaram inicialmente a possibilidade de realizar, por meio das simulações, "experimentos de elevado custo" (E7), que requerem aparelhos sofisticados que são difíceis de ser encontrados nos laboratórios de ensino das escolas. Dadas as condições objetivas em que essas instituições se encontram e os esforços individuais dos professores em promover aulas experimentais com o apoio de experimentos virtuais, resta o uso do projetor multimídia da escola e em muitos casos o computador portátil pessoal do professor. Nesse caso, a abordagem experimental é quase sempre a demonstração.

Os estagiários apontam ainda a ausência de erros nos resultados dos experimentos virtuais como um aspecto vantajoso em relação aos experimentos físicos. O erro experimental pode ser um elemento disparador de reflexões e o principal elemento de aprendizagem na experimentação. O experimento que confirma o dado esperado se reduz à verificação da "teoria" na "prática". Nessa perspectiva, "a atividade experimental, nessa aula, cumpre o mesmo papel que qualquer outro tipo de exercício de exemplo proporcionaria. A novidade não está na experimentação, ela serve apenas para comprovar algo já afirmado anteriormente" (SILVA et al., 2012, p. 143).

Destacamos que nem todos os experimentos virtuais apresentam essa característica, ou seja, não é totalmente verdadeira a concepção de experimento virtual cujos resultados es- 
tão ausentes de erros experimentais (PINHEIRO et al., 2011). Por outro lado, os estudos de Silva et al. (2012, p.18), com professores de ciências dos anos iniciais, comprova que "nas respostas que obtivemos, o erro é tido como algo indesejável nas atividades de experimentação. Ele deve ser descartado quando surge", recuperando o ideário empirista/positivista da modernidade.

Sob esse aspecto, também foi bastante comum o argumento em favor dos experimentos virtuais como elementos lúdicos e motivadores da prática pedagógica em Física, pois "mostra aos alunos que a Física pode ser divertida" (E4), uma vez que "existem simulações físicas que parecem jogos, onde o aluno aprende brincando" (E5). O grupo de alunos entende que essa via de entretenimento pode ser realizada inclusive em casa, uma vez que "os alunos que possuírem acesso à internet em casa, poderiam pesquisar outras simulações e verificar a que foi utilizada em sala de aula" (E8) e assim, "ao chegar em casa em vez de ficar nas redes sociais podem acessar os experimentos e se divertir" (E1). Tal movimento é possível "por causa da curiosidade despertada na aula podendo adquirir o conhecimento em casa" (E5).

A experimentação apoiada em experimentos virtuais como elemento que pode contribuir para despertar a curiosidade dos alunos e motivá-los para a aprendizagem em Física se aproxima do discurso apriorista apontado por Silva et al. (2012). Esses alunos argumentam em favor de um uso da internet como fonte de estudo e palco de execução dos experimentos virtuais que foram trabalhados nas escolas, mas que podem ser explorados pelos alunos em outros espaços nos quais seja possível o acesso a um computador conectado com a internet.

A exploração dos experimentos virtuais fora dos limites da escola é uma possibilidade que indica caminhos para o ensino de Física a distância no contexto da Educação Básica. Cenário que pode ser mais amplamente pensado em função da Resolução CNE/CEB n ${ }^{\circ} 1$, de 2 de fevereiro de 2016 que Define Diretrizes Operacionais Nacionais para o credenciamento institucional e a oferta de cursos e programas de Ensino Médio, de Educação Profissional Técnica de Nível Médio e de Educação de Jovens e Adultos, nas etapas do Ensino Fundamental e do Ensino Médio, na modalidade Educação a Distância, em regime de colaboração entre os sistemas de ensino (BRASIL, 2016).

\section{e) Contribuições dos experimentos virtuais nas aulas de Física}

Na sequência das questões lançadas pelo moderador ao grupo focal, foi interrogado que contribuições o uso de experimentos virtuais trazia para a prática pedagógica em Física. Inicialmente, o argumento foi em favor das contribuições desse recurso para a contextualização de conteúdos abstratos, como apontado por E1: "facilita a visualização dos conteúdos ministrados, pois existem conteúdos que têm um certo grau de abstração e o experimento pode facilitar essa visualização". Um segundo argumento se dá em favor das contribuições como alternativa ao método tradicional de ensino, como apontado por E6: "recurso metodológico que foge do método tradicional que só explica o conteúdo e resolve exercícios matemáticos". 
Além dessas questões, chama atenção o fato dos alunos terem destacado que "com os experimentos o conteúdo pode ser demonstrado" (E6). Não foi feita menção alguma sobre as possibilidades de conduzir uma experimentação investigativa a partir do trabalho com os experimentos virtuais. Em compensação foram bastante apontadas características empiristas/positivistas para o trabalho experimental em Física.

$\mathrm{O}$ argumento em torno das contribuições que os experimentos virtuais podem apresentar para a prática pedagógica em Física se concentram em descrever que a demonstração experimental, apoiada em experimentos virtuais, permite a contextualização, a motivação, o despertar da curiosidade e a visualização dos comportamentos dinâmicos descritos verbalmente ou textualmente no modelo explorado. Esse argumento esteve silenciado diante de características que possam aproximar tal experimentação de abordagens construtivistas como o caso da experimentação investigativa.

\section{g) Metodologia ideal para o trabalho com experimentos virtuais}

Diante do paradoxo entre o debate em defesa da experimentação investigativa e as práticas demonstrativas desenvolvidas pelos estagiários nas micro aulas e na regência das turmas no cenário da Educação Básica, o moderador do grupo focal questionou ao grupo se eles estavam satisfeitos como o trabalho desenvolvido ou se gostariam de ter realizado algo diferente no âmbito da regência.

Em face do questionamento, E1 afirmou que "a melhor metodologia seria aquela que o aluno pudesse mudar os parâmetros, ou seja, levar os estudantes para o laboratório de informática, além de fazer o uso do projetor”. E4 complementou essa fala afirmando que o ideal seria "iniciar a aula colocando uma problemática para poder dar continuidade à aula relacionando com o cotidiano e com conteúdos". E8 complementa essa fala afirmando que o ideal seria partir "de uma problemática inicial". Dentro de uma abordagem construtivista deve-se iniciar a aula com uma problemática que esteja presente no cotidiano do aluno. Os experimentos virtuais podem contribuir para a exploração dessa problemática e assim, favorecer a formulação de hipóteses, visualização de padrões descritos teoricamente, observação de comportamentos de fenômenos analíticos, etc.

No debate do grupo focal, é possível perceber que o moderador ocupou um papel importante na problematização do papel da experimentação. A partir dessa problematização foi possível provocar os estagiários acerca de suas concepções sobre as potencialidades das práticas investigativas e confrontá-las com as experiências desenvolvidas no âmbito do Estágio Supervisionado. Com esta problematização é possível afirmar que as concepções desses estagiários foram ampliadas, reconhecendo as potencialidades das práticas investigativas para além dos experimentos físicos. 


\section{Considerações finais}

Ao longo do componente curricular Estágio Supervisionado 3, os estagiários apresentaram uma boa frequência e se envolveram tanto nos encontros quinzenais, no AVA Moodle e também na regência de aulas na escola. As atividades nesse estágio estiveram concentradas em torno da experimentação em Física apoiada em experimentos virtuais e, para isso, os estagiários foram desafiados a planejar e conduzir aulas de Física com base na experimentação apoiada em experimentos virtuais.

Os planos das micro aulas foram desenvolvidos pelos estagiários sob a orientação do professor responsável pelo Estágio na universidade e os planos de intervenção foram desenvolvidos pelos estagiários em parceria com o professor de Física das escolas. Em ambos os casos, as práticas experimentais se concentraram em torno de demonstrações de experimentos virtuais que exploravam fenômenos naturais analisados no campo da Física. $\mathrm{O}$ uso desses recursos, no ideário desses estagiários, estava relacionado a contextualização, a motivação, o despertar da curiosidade e a visualização dos comportamentos dinâmicos descritos verbalmente ou textualmente no modelo explorado.

$\mathrm{O}$ uso dos experimentos virtuais pode ser motivador para os envolvidos na prática pedagógica, porém é preciso cuidar para que sua exploração didática não se reduza a isso. Do mesmo modo a mediação pedagógica com o uso de experimentos virtuais precisa estar apoiada numa constante problematização do modelo utilizado como base da simulação. Essa problematização é fundamental para que o modelo não seja apreendido pelo sujeito como uma descrição fiel da realidade. O modelo representa a realidade e permite aos sujeitos compreenderem fenômenos naturais a partir de construções aceitas até aquele momento pela comunidade científica. Isso precisa ficar claro no momento de explorar tais recursos de modo a evitar que os sujeitos construam imagens equivocadas sobre como a ciência nasce e/ou se desenvolve.

As práticas pedagógicas com experimentos virtuais embora tenham se concentrado em torno de demonstrações cujas principais funções são despertar a curiosidade dos alunos, motivá-los, contextualizar o conteúdo abordado e ilustrar fenômenos que foram anteriormente expostos pelo professor, não se reduzem a isso, possibilitando a problematização e o encaminhamento de uma experimentação investigativa. Esse movimento proporciona o afastamento de modelos aprioristas e empiristas de aprendizagem em favor de modelos construtivistas.

A análise da experiência por meio da ATD permitiu afirmar que as condições objetivas em que o trabalho docente se dá nas escolas públicas alagoanas têm se constituído num elemento limitador da prática experimental, mesmo quando os experimentos são virtuais. Contribuem para esse fenômeno o pouco tempo para o planejamento didático; a curta duração das aulas; a falta de recursos mínimos de internet, projetor multimídia e computador portátil, ou as péssimas condições dos laboratórios de informática. 
Os estagiários consideram que o uso puro dos experimentos virtuais só se constitui numa alternativa viável para escolas que não possuem laboratório de ciências ou naquelas em que não são realizadas outras formas de experimentação. No entanto, a realidade dos Laboratórios de Ciências das escolas não é muito distinta da realidade dos Laboratórios de Informática e a ausência do Estado na promoção de condições que favoreçam uma autêntica educação científica das próximas gerações pode ser percebida nos resultados dos exames nacionais de avaliação de desempenho de estudantes e na pouca procura por cursos superiores na área das Ciências da Natureza.

O cenário atual favorece aos professores de Física a exploração de um vasto número de recursos digitais que podem contribuir para a experimentação apoiada nos experimentos virtuais. Esse cenário tem exigido dos pesquisadores da área do Ensino de Física, a realização de investigações sobre as contribuições didáticas desse tipo de experimentação, bem como seus limites e potencialidades (MEDEIROS; MEDEIROS, 2002; HEIDEMANN et al., 2012). No entanto, dada a complexidade da relação homem-computador, bem como as implicações do uso de recursos de simulação em estratégias de educação científica, há de se registrar que existem muito mais perguntas que respostas nessa linha de pesquisa.

\section{Referências}

BASSOLI, F. Atividades práticas e o ensino-aprendizagem de ciência(s): mitos, tendências e distorções. Ciência e Educação, Bauru, v. 20, n. 3, p. 579-593, 2014. Disponível em: $<$ http://www.scielo.br/pdf/ciedu/v20n3/1516-7313-ciedu-20-03-0579.pdf>. Acesso em: 14 fev. 2016.

BOGDAN, R.; BIKLEN, S. Investigação qualitativa em educação: uma introdução à teoria e aos métodos. Porto, Portugal: Porto Editora, 1994.

BRASIL. Parecer CNE/CP no 28/2001. Dá nova redação ao Parecer CNE/CP 21/2001, que estabelece a duração e a carga horária dos cursos de Formação de Professores da Educação Básica, em nível superior, curso de licenciatura, de graduação plena. Disponível em: <http://portal.mec.gov.br/cne/arquivos/pdf/028.pdf >. Acesso em: 14 fev. 2016.

Resolução $\mathbf{n}^{\circ}$ 2, de $\mathbf{1}^{\mathbf{0}}$ de julho de 2015. Define as Diretrizes Curriculares Nacionais para a formação inicial em nível superior (cursos de licenciatura, cursos de formação pedagógica para graduados e cursos de segunda licenciatura) e para a formação continuada. Ministério da Educação. Conselho Nacional de Educação. Conselho Pleno. 2015. Disponível em: $<$ http://portal.mec.gov.br/index.php?option=com_docman\&view=download\&alias=17625parecer-cne-cp-2-2015-aprovado-9-junho-2015\&category_slug=junho-2015pdf\&Itemid=30192>. Acesso em: 25 fev. 2016.

Resolução n⿳1, de 2 de fevereiro de 2016. Define Diretrizes Operacionais Nacionais para o credenciamento institucional e a oferta de cursos e programas de Ensino Médio, de 
Educação Profissional Técnica de Nível Médio e de Educação de Jovens e Adultos, nas etapas do Ensino Fundamental e do Ensino Médio, na modalidade Educação a Distância, em regime de colaboração entre os sistemas de ensino. Conselho Nacional de Educação. Câmara de Educação Básica. $2016 . \quad$ Disponível em: $<$ http://portal.mec.gov.br/index.php?option=com_docman\&view=download\&alias=33151resolucao-ceb-n1-fevereiro-2016-pdf\&Itemid=30192>. Acesso em: 9 abr. 2016.

BORGES, O. Formação inicial de professores de Física: formar mais! formar melhor! Revista Brasileira de Ensino de Física, v. 28, n. 2, p. 135-142, 2006. Disponível em: <http://www.scielo.br/pdf/rbef/v28n2/a03v28n2.pdf>. Acesso em: 25 fev 2016.

CARVALHO, P. S. et al. Ensino experimental das ciências: um guia para professores do ensino secundário de Física e Química. 2. ed. Porto: Universidade do Porto, 2013.

CHASSOT, A. Alfabetização científica: uma possibilidade para a inclusão social. Revista Brasileira de Educação, n. 22, p. 89-100, Jan/Fev/Mar/Abr, 2003. Disponível em: <http://www.scielo.br/pdf/rbedu/n22/n22a09>. Acesso em: 22 fev. 2016.

FACHIN, O. Fundamentos de metodologia. 5. ed. São Paulo: Saraiva, 2006.

FLICK, U. Introdução à pesquisa qualitativa. 3. ed. Porto Alegre: Artmed, 2009.

GASPAR, A.; MONTEIRO, I. C. Atividades experimentais de demonstrações em sala de aula: uma análise segundo o referencial da teoria de Vygotsky. Investigações em Ensino de Ciências, $\quad$ v. $10, \quad$ n. 2, p. 227-254, 2005. Disponível em: $<$ http://www.if.ufrgs.br/ienci/artigos/Artigo_ID130/v10_n2_a2005.pdf>. Acesso em: 15 nov. 2014.

GAZETA DE ALAGOAS. Estado abandona laboratórios de escolas. Por Marcelo Gonçalves. 19 de abril de 2015. P. D1-D4.

GIORDAN, M. O papel da experimentação no ensino de Ciências. Química Nova na Escola, n. 10, nov., 1999. Disponível em: <http://qnesc.sbq.org.br/online/qnesc10/pesquisa.pdf>. Acesso em: 24 fev. 2016.

HEIDEMANN, L. A. et al. Experimentos empíricos versus simulações computacionais: uma controvérsia no ensino de Física. In: ENCONTRO DE PESQUISA EM ENSINO DE FÍSICA, 14, 2012, Maresias. Anais...São Paulo, Sociedade Brasileira de Física, 2012. Disponível em: $<$ http://www.sbf1.sbfisica.org.br/eventos/epef/xiv/sys/resumos/T0131-1.pdf>. Acesso em: 8 ago. 2015.

LIMA, K. E.; TEIXEIRA, F. M. A epistemologia e a história do conceito de experimento/experimentação e seu uso em artigos científicos sobre ensino das ciências. In: ENCONTRO NACIONAL DE PESQUISA EM EDUCAÇÃO EM CIÊNCIAS, 8, 2011, Campinas. Anais... 
São Paulo, Associação Brasileira de Pesquisa em Educação em Ciências, 2011. Disponível em: <http://www.nutes.ufrj.br/abrapec/viiienpec/resumos/R0355-1.pdf>. Acesso em: 21 set. 2015.

LIMA, S. C.; TAKAHASHI, E. K. Construção de conceitos de eletricidade nos anos iniciais do ensino fundamental com uso de experimentação virtual. Revista Brasileira de Ensino de Física, $\quad$ v. $\quad 35, \quad$ n. $2,2013 . \quad$ Disponível em: <http://www.scielo.br/pdf/rbef/v35n3/a20v35n3.pdf>. Acesso em: 14 fev. 2016.

LINS, B. O. et al. A experimentação no ensino de Biologia: o que fazem/dizem os professores em uma escola pública de Ourilândia do Norte (PA). Educação Unisinos, v. 18, n. 1, jan-abr, 2014. Disponível em:

$<$ http://revistas.unisinos.br/index.php/educacao/article/view/edu.2014.181.08>. Acesso em: 1 dez. 2014.

LONGHINI, M. D.; MENEZES, L. D. Objeto virtual de aprendizagem no ensino de Astronomia: Algumas situações problemas propostas a partir do software Stellarium. Caderno Brasileiro de Ensino de Física, v. 27, n. 3: p. 433-448, dez. 2010. Disponível em: <https://periodicos.ufsc.br/index.php/fisica/article/view/2175-7941.2010v27n3p433/17169>. Acesso em: 29 jul. 2015.

MARQUEZAN, F. F.; FLEIG, M. T. Diários investigativos no contexto da orientação e supervisão do estágio curricular. In: FREITAS, D. S.; GIORDANI, E. M.; CORRÊA, G. C. Ações educativas e estágios curriculares supervisionados. Santa Maria: Edufsm, 2007. p. 33-46.

MARTÍN, A.; LEÓN, C.; GARCÍA, A. Innovación docente para la integración de autoformación y autoevaluaciónenla plataforma WebCT. Píxel-Bit: Revista de Medios y Educación, n. 44, Enero 2014. Disponível em:

<http://acdc.sav.us.es/pixelbit/images/stories/p44/14.pdf>. Acesso em: 3 dez. 2014.

MEDEIROS, A.; MEDEIROS, C. F. Possibilidades e limitações das simulações Computacionais no ensino da Física. Revista Brasileira de Ensino de Física, v. 24, n. 2, Junho 2002. Disponível em: <http://www.scielo.br/pdf/rbef/v24n2/a02v24n2.pdf>. Acesso em: 14 fev. 2016.

MENEZES, L. C. Novo(?) método(?) para ensinar(?) Física(?). Revista Brasileira de Ensino de Física, v. 2, n. 2, Junho, 1980. Disponível em:

<http://www.sbfisica.org.br/rbef/pdf/vol02a19.pdf>. Acesso em: 9 abr. 2016.

MIRANDA, M. S.; ARANTES, A. R.; STUDART, N. Objetos de aprendizagem no ensino de Física: usando simulações do Phet. In: SIMPÓSIO NACIONAL DE ENSINO DE FÍSICA, 
19, 2011, Manaus. Anais...São Paulo, Sociedade Brasileira de Física, 2011. Disponível em: $<$ http://www.sbf1.sbfisica.org.br/eventos/snef/xix/sys/resumos/T0137-1.pdf>. Acesso em: 7 ago. 2015.

MORAES, R. Uma tempestade de luz: a compreensão possibilitada pela análise textual discursiva. Ciência \& Educação, v. 9, n. 2, p. 191-211, 2003. Disponível em: <http://www.scielo.br/pdf/ciedu/v9n2/04.pdf>. Acesso em: 14 fev. 2016.

MORAES, R.; GALIAZZI, M. C. Análise textual discursiva. 2. ed. rev. Ijuí: Ed. Unijuí, 2013.

Análise textual discursiva: processo reconstrutivo de múltiplas faces. Ciência \& Educação, $\quad$ v. $12, \quad \mathrm{n}^{\mathrm{o}} \quad 1, \quad$ p. 117-128, 2006. Disponível em: <http://www.scielo.br/pdf/ciedu/v12n1/08.pdf>. Acesso em: 14 fev. 2016.

MOREIRA, A. C.; PENIDO, M. C. Sobre as propostas de utilização das atividades experimentais no ensino de Física. In: ENCONTRO NACIONAL DE PESQUISA EM EDUCAÇÃO EM CIÊNCIAS, 7, 2008, Florianópolis. Anais...São Paulo, Associação Brasileira de Pesquisa em Educação em Ciências, 2008. Disponível em: <http://posgrad.fae.ufmg.br/posgrad/viienpec/pdfs/814.pdf>. Acesso em: 23 mar. 2015.

NUNES, E. T. Contribuição dos experimentos virtuais na formação de professores de Física. Trabalho de Conclusão de Curso, Universidade Federal de Alagoas, Campus de Arapiraca, Curso de Licenciatura em Física, 2015.

OLIVEIRA, M.; LAMPERT, J. O estágio curricular como campo de conhecimento e suas especificidades no ensino das artes visuais. In: FREITAS, D. S.; GIORDANI, E. M.; CORREAA, G. C. Ações educativas e estágios curriculares supervisionados. Santa Maria: EDUFSM, 2007. p. 13-32.

OURIQUE, P. A.; GIOVANNINI, O.; CATELLI, F. Fotografando estrelas com uma câmera digital. Revista Brasileira de Ensino de Física, v. 32, n. 1, 2010. Disponível em: <http://www.sbfisica.org.br/rbef/pdf/321302.pdf>. Acesso em: 9 ago. 2015.

PEREIRA, B. B. Experimentação no ensino de ciências e o papel do professor na construção do conhecimento. Cadernos da Fucamp, v. 9, n. 11, 2010. Disponível em: $<$ http://www.fucamp.edu.br/editora/index.php/cadernos/article/view/176>. Acesso em: 15 fev. 2016.

PIMENTA, S. G.; LIMA, M. S. Estágio e docência. São Paulo: Cortez, 2004.

PINHEIRO, A. F.; PESSOA JUNIOR, E. S.; ARAÚJO, M. D. Software de simulação: um recurso facilitador no processo de ensino e aprendizagem de Química no Ensino Médio. In: CONGRESSO NACIONAL DE EDUCAÇÃO (EDUCERE), 12, 2015, Curitiba. 
Anais...Paraná, Pontifícia Universidade Católica do Paraná (PUCPR), Editora Champagnat: Curitiba, 2015. Disponível em:

<http://educere.bruc.com.br/arquivo/pdf2015/16888_7936.pdf>. Acesso em: 19 jan. 2016.

PINHEIRO, A. G.; DIAS, N. L.; ARAÚJO-SILVA, M. A. Experimentando a Física Moderna no ambiente virtual: o interferômetro de Michelson. In: SIMPÓSIO NACIONAL DE ENSINO DE FÍSICA, 19, 2011, Manaus. Anais... São Paulo, Sociedade Brasileira de Física, 2011. Disponível em: <http://www.sbf1.sbfisica.org.br/eventos/snef/xix/sys/resumos/T0498-1.pdf>. Acesso em: 8 ago. 2015.

ROSA, P. R. Fatores que influenciam o ensino de Ciências e suas implicações sobre os curricula dos cursos de formação de professores. Caderno Catarinense de Ensino de Física, v. 16, n. 3, p. 287-313, dez. 1999. Disponível em:

<https://periodicos.ufsc.br/index.php/fisica/article/view/6796/6276>. Acesso em: 24 fev. 2016.

SANTOS, A. S.; SILVA, I. P. Percepção dos professores de Física do ensino médio de Santana do Ipanema-AL acerca da importância do uso de experimentos virtuais na prática pedagógica. In: ENCUENTRO INTERNACIONAL VIRTUAL EDUCA, 17, 2016, San Juan. Anais... Puerto Rico, San Juan, Organização dos Estados Americanos (OEA), 2016. Disponível em: <http://acceso.virtualeduca.red/documentos/ponencias/puerto-rico/619-7451.pdf>. Acesso em: 1 abr. 2016.

SANTOS, E.; SILVA, M. O desenho didático interativo na educação online. Revista Iberoamericana de Educación, n. 49, Jan./Abr., 2009. Disponível em: <http://rieoei.org/rie49a11.htm>. Acesso em: 9 abr. 2016.

SECCO, W.; SECCO, D. Recursos audiovisuais como ferramenta auxiliar no ensino da Física. In: CONGRESSO NACIONAL DE EDUCAÇÃO (EDUCERE), 11, 2013, Curitiba. Anais... Paraná, Pontifícia Universidade Católica do Paraná (PUCPR), Editora Champagnat: Curitiba, 2013.

SILVA JUNIOR, R. C.; ANANIAS, N. T.; CUNHA, J. J. Entendendo o conceito de ácido e base por meio de atividades experimentais simples. In: CONGRESSO NACIONAL DE EDUCAÇÃO (EDUCERE), 11, 2013, Curitiba. Anais... Paraná, Pontifícia Universidade Católica do Paraná (PUCPR), Editora Champagnat: Curitiba, 2013. Disponível em: <http://educere.bruc.com.br/ANAIS2013/pdf/8730_4788.pdf >. Acesso em: 8 ago. 2015.

SILVA, J. A. et al. Concepções e práticas de experimentação nos anos iniciais do ensino fundamental. Linhas Críticas, Brasília, v. 18, n. 35, p. 127-150, jan./abr. 2012. Disponível em: $<$ http://periodicos.unb.br/index.php/linhascriticas/article/view/6828/5498>. Acesso em: 24 fev. 2016. 
SILVA, I. P. O estágio de docência online no curso de Física licenciatura modalidade a distância da UFAL: formando recursos humanos para além dos muros da escola. Revista EDaPECI: Educação a Distância e Práticas Educativas Comunicacionais e Interculturais, v. 11, p. 21-45, $2012 . \quad$ Disponível em: <http://www.seer.ufs.br/index.php/edapeci/article/view/876/774>. Acesso em: 14 jan. 2016.

SILVA, I. P.; LESSA, R. K. C.; MERCADO, L. P. L. Mediação pedagógica em fóruns de discussão no contexto da experiência do estágio de docência online. Revista EDaPECI: Educação a Distância e Práticas Educativas Comunicacionais e Interculturais, v. 15, p. 30-56, 2015. Disponível em: <http://www.seer.ufs.br/index.php/edapeci/article/view/3076/pdf>. Acesso em: 14 jan. 2016.

SILVA, I. P.; MATA, C. S. Formação de professores de Física para a docência online no contexto do estágio supervisionado. In: SEMINÁRIO NACIONAL DO EDAPECI, 6, 2015, Maceió. Anais... Maceió, Universidade Federal de Alagoas e Universidade Federal de Sergipe, p. 97-110, 2015. Disponível em:

<http://soac.ufs.br/index.php/edapeci/6edapeci/paper/view/103/66>. Acesso em: 14 jan. 2015.

SILVA, I. P.; MERCADO, L. P. Levantamento dos temas TIC e EAD na biblioteca virtual Educ@. Cadernos de Pesquisa v. 45, n. 158, p. 970-988, out./dez. 2015. Disponível em: $<$ http://www.scielo.br/pdf/cp/v45n158/1980-5314-cp-45-158-00970.pdf>. Acesso em: 14 fev. 2016.

SILVA, I. P.; VIEIRA, J. E. L. Análise da segunda oferta do estágio de docência online no curso de licenciatura em Física modalidade a distância da UFAL. In: SEMINÁRIO NACIONAL DO EDAPECI, 6, 2015, Maceió. Anais... Maceió, Universidade Federal de Alagoas e Universidade Federal de Sergipe, p. 111-125, 2015. Disponível em: <http://soac.ufs.br/index.php/edapeci/6edapeci/paper/view/104/67>. Acesso em: 14 jan. 2015.

SOUZA, C. R.; ARANTES, A. R.; STUDART, N. Objetos de aprendizagem e o processo de ensino-aprendizagem: análise de controvérsias no ensino de Física. In: ENCONTRO DE PESQUISA EM ENSINO DE FÍSICA, 14, 2012, Maresias. Anais... São Paulo, Sociedade Brasileira de Física, 2012. Disponível:

$<$ http://www.sbf1.sbfisica.org.br/eventos/epef/xiv/sys/resumos/T0240-1.pdf>. Acesso em: 8 ago. 2015.

YAMAMOTO, I.; BARBETA, V. B. Simulações de experiências como ferramenta de demonstração virtual em aulas de teoria de Física. Revista Brasileira de Ensino de Física, v. 23, n. 2, junho, 2001. Disponível em: <http://www.scielo.br/pdf/rbef/v23n2/v23n2a13.pdf>. Acesso em: 14 fev. 2016. 